\title{
The efficacy of XP-endo SHAPER (XPS) in cleaning the apical third of the root canal
}

\author{
Slavoljub Živković1, Jelena Nešković ${ }^{1}$, Milica Jovanović-Medojević ${ }^{1}$, Marijana Popović-Bajić1, \\ Marija Živković-Sandić \\ 'University of Belgrade, Faculty of dental medicine, Department of Restorative Dentistry and Endodontics, Belgrade, \\ Serbia; \\ 2University of Belgrade, Faculty of dental medicine, Department of Orthodontics, Belgrade, Serbia
}

\begin{abstract}
SUMMARY
Introduction The aim of this study was to evaluate the efficacy of new rotary NiTi instrument XP endo SHAPER (XPS) used with conventional irrigation protocol on the root canal cleaning in the apical area.

Material and methods The research was conducted in vitro on 40 extracted single-rooted teeth divided into the four groups. Instrumentation in the first group was performed using iRa Ce NiTi rotary instruments, in the second group the same instruments were used plus XP endo FINISHER (XPF) for smear layer removal. In the third group, canal instrumentation was done using new instrument XPS, and in the fourth XPS instruments plus XPF was used. During the instrumentation $2 \% \mathrm{NaOCl}$ solution was used for rinsing canals. The SEM analysis of the cleaning quality in the apical third of the canal was performed on longitudinal root cross-sections and standardized microphotography with a 2000x magnification.

Results The thickest smear layer in the apical third was recorded in the first group (iRa Ce) NiTi instruments (2.12), and somewhat less in the group with the new XPS instrument (1.95). An identical and somewhat smaller amount of smear layer was registered in the second and fourth groups where XPF was used with the final irrigant $(1.64)(p<0.001)$. Conclusion The application of only one instrument (XPS) in the canal enabled efficient cleaning of a very complex apical third. Cleaning was more efficient when XPF was used with final irrigant after the canal instrumentation.

Keywords: XP endo SHAPER; XP endo FINISHER; smear layer; conventional irrigation
\end{abstract}

\section{INTRODUCTION}

Complex anatomy of the root canal system and inadequate cleaning using the existing instruments and techniques are still significant and current problems of endodontic treatment $[1,2]$. It has been confirmed that even after careful selection of hand or rotary files, almost $30-50 \%$ of the wall surface remains untouched [3].

Cleaning the apical third of the root canal is a challenge due to anatomical specificities (constrictions, ramifications, additional canals) [3] and due to small diameter of the apical preparation that additionally complicates canal debridement [4]. The quantity of irrigants, technique and irrigation protocol are very important for efficient cleaning of the root canal system, since it is the only way to reach untouched and inaccessible areas of the canal $[5,6]$.

Chemo-mechanical procedures provide significant reduction in the number of bacteria in the main canal, but not complete disinfection of the canal system [7]. Therefore, the realistic goal of endodontic treatment is to reduce the number of bacteria in the canal system on the level that enables effective reparation of damaged periapical tissues $[8,9]$. Mechanical instrumentation with copious irrigation removes the largest number of bacteria from the canal, but irrigants with antibacterial properties are necessary for optimal canal disinfection $[10,11,12]$. The most frequently used root canal irrigants are $\mathrm{NaOCl}$ (due to the strong antibacterial effect [13] and exceptional solvent effect of the organic part of dentine [14]), or chlorhexidine (due to prolonged antibacterial effect on numerous bacteria in the canal) $[15,16,17]$.

It has also been confirmed that irrigation techniques based on solution activation in the canal (passive ultrasonic irrigation $[18,19]$, agitation with new instruments - XP Endo FINISHER (XPF) $[6,20]$ or laser [21]) provide more efficient penetration of irrigants, and more efficient cleaning of the complete root canal system. The research has also confirmed that physical and chemical properties of irrigants enable smear layer dissolution on the canal walls and significantly contribute to its removal [22, 23]. This significantly increases the quality of bond between the sealer and dentin walls and significantly affects the quality and outcome of the endodontic treatment $[24,25]$.

The aim of this article was to evaluate (using SEM) the efficacy of new rotary NiTi instrument XP endo SHAPER (XPS) used with conventional irrigation protocol on the root canal cleaning in the apical area.

\section{MATERIAL AND METHODS}

The study was conducted on 40 extracted human teeth (upper incisors), which were stored up to the experiment in a $0.01 \%$ 
solution of $\mathrm{NaOCl}$ at the temperature of $4{ }^{\circ} \mathrm{C}$. After forming out the access cavity and checking the passage of the canal with hand instrument (ISO 15) in all teeth, the working length (1 $\mathrm{mm}$ shorter than the length at which the tip of the hand-file appears on the apex) was determined. Pink wax ball was placed at the top of each root to prevent leakage of the irrigants during instrumentation.

Teeth were divided into the 4 groups (10 teeth each) using the method of random choice. One researcher performed all root canal preparations. Plastic syringes of $2 \mathrm{ml}$ volume and the appropriate needles gauge 27 were used for irrigation.

Group 1- in the first group preparation was formed using the basic set of NiTi rotating instruments iRaCe (FKG, Dentaire, Swiss) [26] with 3 instruments (R1 \# 15/06; R2 \# 25/04, R3 \# $30 / 04$ ) and conventional irrigation of $2 \% \mathrm{NaOCl}$ solution (Chloraxid $2 \%$, Cerkamed, Poland). The canal was irrigated with $2 \mathrm{ml}$ of $\mathrm{NaOCl}$ solution before each and after the last NiTi instrument (total of $8 \mathrm{ml}$ per canal).

Group 2- in the second group the canal instrumentation was done identically as in the first group, but after the preparation, XPF (FKG, Dentaire, Swiss) was used.After the canal was filled with irrigant $(1 \mathrm{ml} \mathrm{NaOCl}) \mathrm{XPF}$ was used with slow pulling in and pulling out movements for 1 minute and at the speed of $800 \mathrm{rpm}$. After the withdrawal of the instrument, the canal was irrigated with one more milliliter of solution.

Group 3- in the third group canal preparation was performed with new NiTi rotary instrument XP endo SHAPER (FKG, Dentaire, Swiss) [26] (one instrument \# 30/04) with constant irrigation with $2 \% \mathrm{NaOCl}$ solution before and after the instrumentation (total $4 \mathrm{ml}$ per canal). The instrument was placed into the canal filled with irrigant and with gentle movements of pulling in and pulling out at the speed of $800 \mathrm{rpm}$, the canal was prepared to the working length.

Group 4- in the fourth group instrumentation of the canal was done using XP endo SHAPER, and for more efficient cleaning after instrumentation, XP endo FINISHER was used.

The crowns of all teeth were cut at the enamel-cement joint, and then the roots were separated into the two halves with the diamond disc and sharp knife. The halves were prepared for SEM analysis (JOEL, JSM 6460LV, Japan). The apical third of the canal ( $3 \mathrm{~mm}$ from the apical preparation) was analyzed, so that 5 standardized microphotographs were taken at 2000x for each sample (half of the tooth). For qualitative evaluation of the residual smear layer on dentin walls in the apical segment of the canal, Hilsman and al. criteria [27] were used:

1- no smear layer, dentinal tubules open

2- small amount of smear layer, several dentinal tubules open

3- non-homogeneous smear layer covers the canal wall, small number of dentinal tubules open

4- the entire wall of the canal covered with smear layer, no open dentinal tubules

5- non-homogeneous smear layer covering the entire wall of the canal

SEM images (400 in total) were evaluated by two independent researchers. The obtained results were analyzed in the SPSS program using the parameters of descriptive statistics and analysis of variance.

\section{RESULTS}

The results of SEM analysis are shown in Table 1 and Figures 1-4.

The most smear layer in the apical third was recorded in the group where the instrumentation was done only by $\mathrm{NiTi}$ rotating instruments iRaCe (2.12), then in the group where XP endo SHAPER (1.95) was used. In the second (iRaCe and XP endo FINISHER ) and the fourth group (XP endo SHAPER and XP endo FINISHER), an identical and slightly less amount

Table 1. Smear layer removal in the apical third of the root canal Tabela 1. Procena razmaznog sloja u apeksnoj trećini kanala korena zuba

\begin{tabular}{|l|c|c|c|c|c|c|}
\hline $\begin{array}{l}\text { Group } \\
\text { Grupa }\end{array}$ & $\mathbf{N}$ & $\mathbf{x}$ & SD & Med & Min & Max \\
\hline iRaCe & 100 & 2.12 & 1.00 & 2.00 & 1.00 & 4.00 \\
\hline iRaCe+XPF & 100 & 1.64 & 0.70 & 2.00 & 1.00 & 3.00 \\
\hline XPE & 100 & 1.95 & 0.98 & 2.00 & 1.00 & 4.00 \\
\hline XPE+XPF & 100 & 1.64 & 0.72 & 1.50 & 1.00 & 3.00 \\
\hline $\begin{array}{l}\text { Total } \\
\text { Ukupno }\end{array}$ & 400 & 1.84 & 0.88 & 2.00 & 1.00 & 4.00 \\
\hline
\end{tabular}

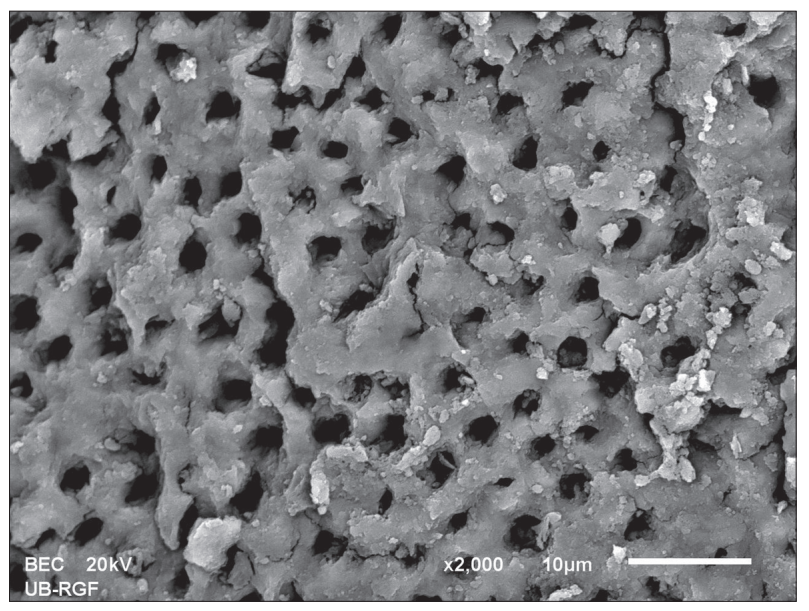

Figure 1. Representative microphotography of the apical third of the group 1 (iRa Ce). Small amount of smear layer (grade 2) (SEM $\times 2000)$

Slika 1. Reprezentativna mikrofotografija apeksne trećine iz grupe 1 (iRa Ce). Mala količina razmaznog sloja (ocena 2) (SEM ×2000)

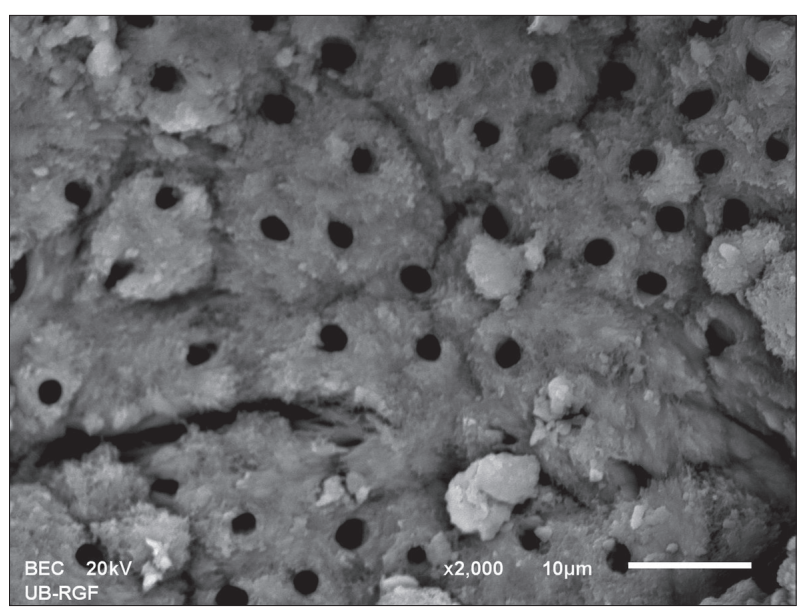

Figure 2. Representative microphotography of the apical third of the group 2 (iRa $\mathrm{Ce}+\mathrm{XPF}$ ). Small amount of smear layer with great number of open dentinal tubules (grade 2) $($ SEM $\times 2000)$

Slika 2. Reprezentativna mikrofotografija apeksne trećine iz grupe 2 (iRa Ce + XPF). Mala količina razmaznog sloja sa dosta otvorenih tubula (ocena 2) $($ SEM $\times 2000)$ 


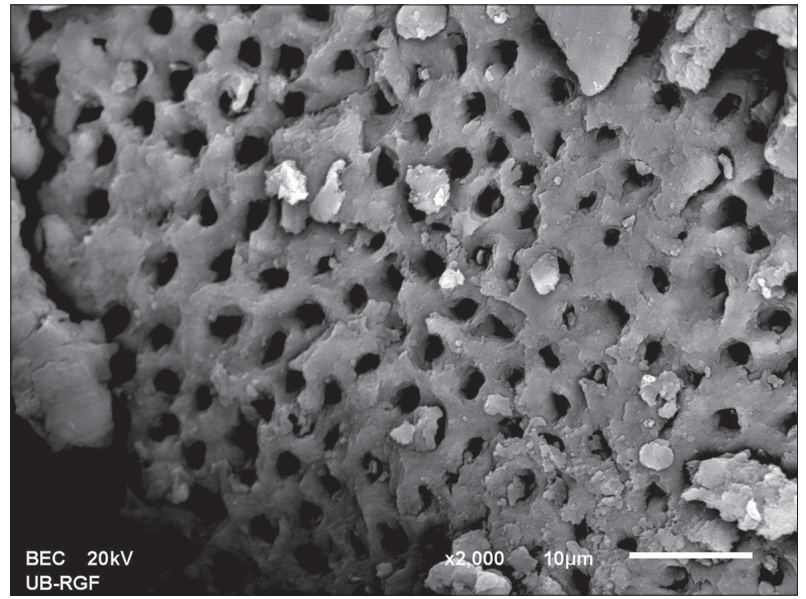

Figure 3. Representative microphotography of the apical third of the group 3 (XPS). Small amount of smear layer (grade 2) (SEM $\times 2000$ )

Slika 3. Reprezentativna mikrofotografija apeksne trećine iz grupe 3 (XPS). Mala količina razmaznog sloja (ocena 2) $($ SEM ×2000)

of smear layer (1.64) was detected. A single-factor analysis of variance indicated statistically significant difference in average scores between the groups $(\mathrm{P}<0.001)$ (Table 1$)$. This difference was significant between the first (iRaCe) and the second group (iRaCe and XPendo FINISHER), and between the first (iRaCe) and the fourth group (XP endo SHAPER and XP endo FINISHER) (Table 1).

\section{DISCUSSION}

Chemo-mechanical preparation of the root canal is one of the essential factors in the control of endodontic infection $[3,7$, 22 ] and the removal of smear layer from the root canal walls is significant clinical parameter for the endodontic treatment success $[13,15,25]$. The most challenging area in root canal cleaning and smear layer removal is the apical third of the canal $[6,12,18,21]$. Inaccessibility of this segment of the canal due to inadequate diameter of the apical preparation makes difficult to achieve exposure of this part of the canal to adequate time, volume and concentration of irrigants [7, 10, 13, 28, 29, 30]. Therefore, in this study, canal instrumentation and irrigation were performed in simple canal systems (single rooted teeth), according to the same protocol (all canals were instrumented by the same practitioner) with the same irrigant $(2 \% \mathrm{NaOCl})$ and irrigation technique (conventional, continuous).

The results indicated significantly more efficient cleaning and removing smear layer in the apical third of the root canal, when XP endo FINISHER (XPF) was used after complete instrumentation with NiTi rotating instruments (iRaCe, XP endo SHAPER). XPF enabled more effective smear layer removal from the apical third of the canal, due to its specific design and changing its shape during rotation in the canal and reaching inaccessible areas in the apical part of the canal $[6,18,20,26]$. It also significantly reduced bacteria from the hard-to-reach areas due to irrigant activation at a speed of $800 \mathrm{rpm}$ [6]. It is well known that success in root canal cleaning depends on the instrumentation technique, selection of irrigants and irrigation technique $[2,8,10,12,16,18,24]$.

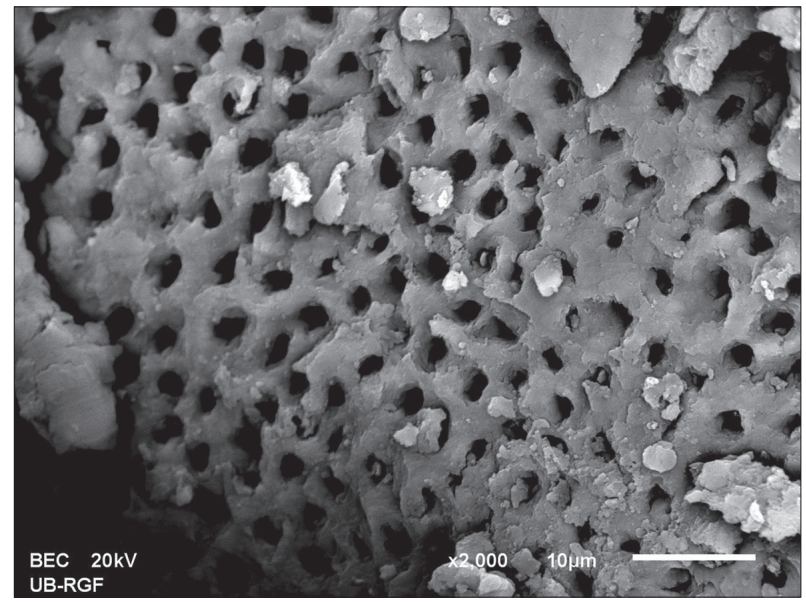

Figure 4. Representative microphotography of the apical third of the group 4 (XPS + XPF). Small amount of smear layer with the number of open dentinal tubules (grade 2) $($ SEM $\times 2000)$

Slika 4. Reprezentativna mikrofotografija apeksne trećine iz grupe 4 (XPS + XPF). Mala količina razmaznog sloja sa dosta otvorenih tubula (ocena 2) $($ SEM $\times 2000)$

In this study, conventional and continuous irrigation protocol with $2 \% \mathrm{NaOCl}$ solution was used in all groups while the canal instrumentation in the first and second group was performed with iRaCe NiTi rotary instruments (3 instruments), and in the third and fourth group with XP endo SHAPER (1 instrument). Better cleaning of the apical part of the canal was observed after XPS was used but without significant difference. Both instrument systems offer the same apex preparation size (\# 30/04 in iRaCe and \# 30/04 with XP endo SHAPER), but specific design of XPS and its flexibility allowed it to contract and expand within the canal, and therefore reaches those zones that conventional instruments cannot reach [28].

It is interesting that more efficient removal of the smear layer in the apical third was achieved when the preparation was done with one instrument only and significantly smaller amount of irrigant. Although higher bacterial reduction in the canal system is expected after prolonged irrigation $[13,31]$, somewhat better cleaning could be explained by the instrumentation technique, and rotational speed $(800 \mathrm{rpm})$, but also the specific design of XPS. Namely, the shape like snake and superelasticity of XP ENDO SHAPER allowed it to expand in the canal and reach inaccessible parts (canals, lateral canals, apex ramifications) $[20,26,28,33,34]$.

Efficient cleaning of the apical third of the root canal instrumented with iRaCe iinstruments is the result of satisfactory diameter in apex (30/04) that provides irrigant access on smear layer in this area $[25,28,30]$. It has been confirmed that the preparation of the canal with RaCe instruments causes significantly less transportation of cut dentine into the apical part of the canal compared to other rotating NiTi instruments [20, 35]. The smaller amount of smear layer obtained with the same instruments is related to slightly higher speed of these instruments $(600 \mathrm{rpm})$ than the most common speeds of other NiTi instruments (150-300 rpm) [20,36].

Since the presence of bacteria in the root canal system causes poor prognosis of endodontic treatment, the main precondition for success is maximum elimination of bacteria by chemo-mechanical instrumentation $[7,30]$. $\mathrm{NaOCl}$ is the most commonly used solution for irrigation of the root canal due to 
its effective antibacterial and tissue dissolution effect as well as its availability [30]. Irrigation technique has also effect on smear layer removal [6]. The advantage of the intermittent irrigation procedure (in 3 steps) in relation to the continuous is that the increase in the irrigation cycle increases its cumulative effect and fresh irrigants improve the quality and speed of bacterial biofilm removal from the canal system $[6,37,38]$.

\section{CONCLUSION}

New rotary NiTi instrument XP endo SHAPER (1 instrument) and iRaCe set (3 instruments) provided efficient cleaning of the apical third of the root canal. Following the application of XP endo FINISHER after completed instrumentation more efficient removal of smear layer in the apical third of the root canal was achieved.

\section{REFERENCES:}

1. Peters OA, Laib A, Göhring TN, Barbakow F. Changes in root canal geometry after preparation assessed by high-resolution computed tomography. J Endod. 2001; 27:1-6. [DOl:10.1097/00004770200101000-00001] [PMID: 11487156]

2. Chen JE, Nurbakhsh B, Layton G, Bussmann M, Kishen A. Irrigation dynamics associated with positive pressure, apical negative pressure and passive ultrasonic irrigations: a computational fluid dynamics analysis. Aust Endod J. 2014; 40:54-60. [DOI: 10.1111/ aej.12027] [PMID: 25244218]

3. Gulabivala K, Patel B, Evans G, Ng YL. Effects of mechanical and chemical procedures on root canal surfaces. Endod Topics. 2005; 10:103-22. [DOI: 10.1111/j.1601-1546.2005.00133.x]

4. Trope M, Debelian G. XP Endo FINISHER file-The next step in restorative endodontics. Endod Pract US. 2015; 8:22-4.

5. Haapasalo M, Shen Y, Wang Z, Gao Y. Irrigation in endodontics. Br Dent J. 2014; 216:299-303. [DOI: 10.1038/sj.bdj.2014.204] [PMID: 24651335]

6. Bao P, Shen Y, Lin J, Haapasalo M. In Vitro Efficacy of XP-endo FINISHER with 2 Different Protocols on Biofilm Removal from Apical Root Canals. J Endod. 2017; 43:321-5. [DOI: 10.1016/j. joen.2016.09.021] [PMID: 27939826]

7. Siqueira JF Jr, Rôças IN. Clinical implications and microbiology of bacterial persistence after treatment procedures. J Endod. 2008; 34:1291-301. [DOI: 10.1016/j.joen.2008.07.028]

8. Huang X, Ling J, Wei X, Gu L. Quantitative evaluation of debris extruded apically by using ProTaper Universal Tulsa rotary system in endodontic retreatment. Endod. 2007; 33:1102-5. [DOI: 10.1016/j. joen.2007.05.019] [PMID: 17931943]

9. Topçuoğlu HS, Akıı A, Tuncay Ö, Dinçer AN, Düzgün S, Topçuoğlu G. Evaluation of debris extruded apically during the removal of root canal filling material using ProTaper, D-RaCe, and R-Endo rotary nickel-titanium retreatment instruments and hand files. I Endod. 2014; 40:2066-9. [DOl: 10.1016/j.joen.2014.09.004] [PMID: 25443282]

10. Gu LS, Kim JR, Ling J, Choi KK, Pashley DH, Tay FR. Review of contemporary irrigant agitation techniques and devices. I Endod. 2009; 35:791-804. [DOI: 10.1016/j.joen.2009.03.010] [PMID: 19482174]

11. Jaju S, Jaju PP. Newer root canal irrigations in horizon: A review. Int J Dent. 2011; 2011:851359. [DOI: 10.1155/2011/851359] [PMID: 22190936]

12. Guerreiro-Tanomaru JM, Loiola LE, Morgental RD, Leonardo Rde T, Tanomaru-Filho M. Efficacy of four irrigation needles in cleaning the apical third of root canals. Braz Dent J. 2013; 24(1):21-4. [PMID: 23657408]

13. Siqueira JF Jr' Rôças IN, Favieri A, Lima KC. Chemomechanical reduction of the bacterial population in the root canal after in- strumentation and irrigation with $1 \%, 2.5 \%$, and $5.25 \%$ sodium hypochlorite. J Endod. 2000; 26:331-4. [DOl: 10.1097/00004770200006000-00006] [PMID: 11199749]

14. Zehnder M, Kosicki D, Luder H, Sener B, Waltimo T. Tissue-dissolving capacity and antibacterial effect of buffered and unbuffered hypochlorite solutions. Oral Surg Oral Med Oral Pathol Oral Radiol Endod. 2002; 94:756-62. [DOI: 10.1067/moe.2002.128961] [PMID: 12464903]

15. Ohara P, Torabinejad M, Kettering JD .Antibacterial effects of various endodontic irrigants on selected anaerobic bacteria. Endod Dent Traumatol. 1993; 9(3):95-100. [PMID: 8243347]

16. Rosenthal S, Spångberg L, Safavi K. Chlorhexidine substantivity in root canal dentin. Oral Surg Oral Med Oral Pathol Oral Radiol Endod. 2004; 98:488-92. [DOI: 10.1016/S1079210403004815] [PMID: 15472666]

17. Shen Y, Qian W, Chung C, Olsen I, Haapasalo M Evaluation of the effect of two chlorhexidine preparations on biofilm bacteria in vitro: a three-dimensional quantitative analysis. J Endod. 2009; 35:981-5. [DOI: 10.1016/j.joen.2009.04.030]

18. Blank-Gonçalves LM, Nabeshima CK, Martins GH, Machado ME. Qualitative analysis of the removal of the smear layer in the apical third of curved roots: conventional irrigation versus activation systems. J Endod. 2011; 37(9):1268-71. [DOI: 10.1016/j. joen.2011.06.009] [PMID: 21846545]

19. Haapasalo M, Wang Z, Shen Y, Curtis A, Patel P, Khakpour M. Tissue dissolution by a novel multisonic ultracleaning system and sodium hypochlorite. J Endod. 2014; 40:1178-81. [DOl: 10.1016/j. joen.2013.12.029] [PMID: 25069928]

20. ŽivkovićS, Nešković J, Jovanović-Medojević M, Popović-Bajić M, Živković-Sandić M. XP-Endo FINISHER: A new solution for smear layer removal. Ser Dent J. 2015; 62:122-6. [DOI: 10.1515/sdj-20150013]

21. Ayranci LB, Arslan H, Akcay M, Capar ID, Gok T, Saygili G. Effectiveness of laser-assisted irrigation and passive ultrasonic irrigation techniques on smear layer removal in middle and apical thirds. Scanning. 2016; 38(2):121-7. [DOI: 10.1002/sca.21247] [PMID: 26183211]

22. Violich DR, Chandler NP. The smear layer in endodontics - a review. Int Endod J. 2010; 43:2-15. [DOI: 10.1111/j.1365-2591.2009.01627.x] [PMID: 20002799]

23. Silva PV, Guedes DF, Nakadi FV, Pécora JD, Cruz-Filho AM. Chitosan: a new solution for removal of smear layer after root canal instrumentation. Int Endod J. 2013; 46(4):332-8. [DOI: 10.1111/j.13652591.2012.02119.x] [PMID: 22970844]

24. Andrabi SM, Kumar A, Kumar Tewari R, Kumar Mishra S, Iftekhar $H$. An In Vitro SEM Study on the Effectiveness of Smear Layer Removal of Four Different Irrigations. Iran Endod J. 2012; 7:171-6. [PMID: 23130075]

25. Kamel WH, Kataia EM. Comparison of the efficacy of Smear Clear with and without a canal brush in smear layer and debris removal from instrumented root canal using WaveOne versus ProTaper: a scanning electron microscopic study. J Endod. 2014; 40:446-50. [DOI: 10.1016/j.joen.2013.09.028] [PMID: 24565669]

26. FKG Dentaire SA The XP-Endo SHAPER File Brochure. Available at: http//www.fkg.ch/products/endodontics/preparation/Xp-Endo SHAPER. Accesed December 1, 2016

27. Hülsmann M, Rümmelin C, Schäfers F. Root canal cleanliness after preparation with different endodontic handpieces and hand instruments: a comparative SEM investigation. J Endod. 1997; 23(5):301-6. [DOI: 10.1016/S0099-2399(97)80410-4] [PMID: 9545932]

28. Neves MA, Provenzano JC, Rôças IN, Siqueira JF Jr. Clinical Antibacterial Effectiveness of Root Canal Preparation with Reciprocating Single-instrument or Continuously Rotating Multi-instrument Systems. J Endod. 2016; 42:25-9. [DOl: 10.1016/j.joen.2015.09.019] [PMID: 26549221]

29. Trope M, Debelian G. Microbial control: the first stage of root canal treatment. Gen Dent. 2009; 57:580-8. [PMID: 19906610]

30. Rôças IN, Provenzano JC, Neves MA, Siqueira JF Jr. Disinfecting Effects of Rotary Instrumentation with Either 2.5\% Sodium Hypochlorite or 2\% Chlorhexidine as the Main Irrigant: A Ran- 
domized Clinical Study. Endod. 2016; 42:943-7. [DOI: 10.1016/j. joen.2016.03.019] [PMID: 27142579]

31. Alves FR, Almeida BM, Neves MA, Rôças IN, Siqueira JF Jr. Timedependent antibacterial effects of the self-adjusting file used with two sodium hypochlorite concentrations. I Endod. 2011;37:1451-5. [DOI: 10.1016/i.joen.2011.06.001] [PMID: 21924201]

32. Retamozo B, Shabahang S, Johnson N, Aprecio RM, Torabinejad $\mathrm{M}$. Minimum contact time and concentration of sodium hypochlorite required to eliminate Enterococcus faecalis.) Endod. 2010; 36(3):520-3. [DOI: 10.1016/j.joen.2009.12.005] [PMID: 20171375]

33. Vera J, Siqueira JF Jr, Ricucci D, Loghin S, Fernández N, Flores B, et al. One-versus two-visit endodontic treatment of teeth with apical periodontitis: a histobacteriologic study. J Endod. 2012; 38(8):104052. [DOI: 10.1016/j.joen.2012.04.010] [PMID: 22794203]

34. Nair PN, Henry S, Cano V, Vera J. Microbial status of apical root canal system of human mandibular first molars with primary apical periodontitis after "one-visit" endodontic treatment. Oral Surg Oral Med Oral Pathol Oral Radiol Endod. 2005; 99:231-52. [DOI: 10.1016/j.tripleo.2004.10.005] [PMID: 15660098]
35. Schäfer E, Vlassis M. Comparative investigation of two rotary nickel-titanium instruments: ProTaper versus RaCe. Part 2. Cleaning effectiveness and shaping ability in severely curved root canals of extracted teeth. Int Endod J. 2004; 37:239-48. [DOI: 10.1111/j.01432885.2004.00783.x] [PMID: 15056350]

36. Poulsen WB, Dove SB, del Rio CE. Effect of Nickel-Titanium EngineDriven Instruments Rotational Speed on Root Canal Morphology. J Endod. 1995; 21:609-12. [DOI: 10.1016/S0099-2399(06)81113-1] [PMID: 8596082]

37. Druttman AC, Stock C). An in vitro comparison of ultrasonic and conventional methods of irrigant replacement. Int Endod J. 1989; 22(4):174-8. [PMID: 2637222]

38. Macedo RG, Verhaagen B, Wesselink PR, Versluis $M$, van der Sluis LW. Influence of refreshment/activation cycles and temperature rise on the reaction rate of sodium hypochlorite with bovine dentine during ultrasonic activated irrigation. Int Endod J. 2014; 47(2):147-54. [DOI: 10.1111/iej.12125] [PMID: 23701220]

Received: 04.09.2017 • Accepted: 27.11.2017 


\title{
XP-endo SHAPER (XPS): efikasnost u čišćenju apeksne trećine kanala
}

\author{
Slavoljub Živković1, Jelena Nešković ${ }^{1}$, Milica Jovanović-Medojević ${ }^{1}$, Marijana Popović-Bajić1, \\ Marija Živković-Sandić \\ ${ }^{1}$ Univerzitet u Beogradu, Stomatološki fakultet, Klinika za bolesti zuba, Beograd, Srbija; \\ Univerzitet u Beogradu, Stomatološki fakultet, Klinika za ortopediju vilica, Beograd, Srbija
}

\begin{abstract}
KRATAK SADRŽAJ
Uvod Cilj ovog rada je bio da se SEM analizom proceni efikasnost čišćenja apeksne trećine kanala korena primenom novog rotirajućeg NiTi instrumenta XPS uz protokol konvencionalne irigacije.

Materijal i metode rada Istraživanje je realizovano u in vitro uslovima na 40 ekstrahovanih jednokorenih zuba podeljenih u četiri grupe. Instrumentacija kanala u prvoj grupi je izvedena setom iRa Ce NiTi rotirajućih instrumenata, a u drugoj je nakon instrumentacije ovim setom za uklanjanje razmaznog sloja korišćen XPF. U trećoj grupi je instrumentacija kanala realizovana novim instrumentom XPS, a u četvrtoj je posle završene instrumentacije takođe korišćen XPS. Irigacija kanala korena u svim grupama je sprovedena $2 \%$ rastvorom $\mathrm{NaOCl}$ primenom konvencionalnog protokola. SEM analiza kvaliteta čišćenja apeksne trećine kanala je realizovana na uzdužnim presecima korenova i standardizovanim mikrofotografijama na uveličanju od 2000 puta.

Rezultati Dobijeni rezultati su pokazali da je najviše razmaznog sloja u apeksnoj trećini zabeleženo u grupi gde je instrumentacija realizovana setom iRa Ce NiTi instrumenata $(2,12)$, a nešto manje u grupi sa novim instrumentom XPS $(1,95)$. Identična i nešto manja količina razmaznog sloja je registrovana u drugoj i četvrtoj grupi, gde je posle završene instrumentacije korišćen XPF $(1,64)(p<0,001)$. Zaključak Primena samo jednog instrumenta (XPS) u instrumentaciji kanala obezbeđuje efikasno čišćenje vrlo kompleksne apeksne trećine. Ovo čišćenje je značajno efikasnije posle primene XPF nakon završene instrumentacije kanala.

Ključne reči: XP-endo SHAPER; XP-endo FINISHER; razmazni sloj; konvencionalna irigacija
\end{abstract}

\section{UVOD}

Kompleksna i složena anatomija kanalskog sistema zuba i nemogućnost adekvatnog čišćenja ovog prostora postojećim instrumentima i tehnikama još uvek su značajan i aktuelan problem endodontskog lečenja $[1,2]$. Čak ni pažljivim izborom ručnih ili mašinskih turpija nije moguće dopreti do svih delova kanala, pa skoro 30-50\% površine zidova ostaje netaknuto [3].

Poseban problem u čišćenju predstavlja apeksna trećina kanala korena, kako zbog anatomskih specifičnosti (istmusi, ramifikacije, dodatni kanali) [3] tako i zbog malog dijametra apeksne preparacije koja dodatno otežava debridman kanala [4]. Za efikasno čišćenje kanalskog sistema vrlo je značajna i količina irigansa, odnosno tehnika i protokol irigacije, s obzirom na to da je to jedini način da se dopre do netaknutih i nepristupačnih površina kanala $[5,6]$.

Hemomehaničke procedure obezbeđuju znatno smanjenje broja bakterija u glavnom kanalu, ali ne i potpunu dezinfekciju kompletnog kanalskog sistema [7]. Zato se smatra da je realni cilj endodontskog tretmana u stvari smanjenje broja bakterija u kanalskom sistemu na nivo koji će omogućiti efikasnu reparaciju oštećenih periapikalnih tkiva $[8,9]$. Mehaničkom instrumentacijom uz obilnu irigaciju se uklanja najveći broj bakterija iz kanalskog sistema, ali je za optimalnu dezinfekciju kanala neophodan i irigans sa antibakterijskim svojstvima $[10,11,12]$.

Najčešće korišćena sredstva za irigaciju kanala su sigurno $\mathrm{NaOCl}$ (zbog snažnog antibakterijskog efekta [13] i izuzetnog rastvaračkog efekta organskog dela dentina [14]), odnosno hlorheksidin (zbog izuzetnog i produženog antibakterijskog efekta na brojne bakterije u kanalu) $[15,16,17]$. Potvrđeno je takođe da se tehnikama irigacije koje se baziraju na nekoj vrsti aktivacije rastvora u kanalu (pasivna ultrazvučna irigacija $[18,19]$, agitacija novim instrumentima - XP-endo FINISHER [6, 20] ili laser [21] - obezbeđuje efikasnija penetracija irigansa, odnosno efikasnije čišćenje kompletnog kanalskog sistema.
Istraživanja su takođe potvrdila da sredstva za irigaciju svojim fizičkim i hemijskim svojstvima omogućavaju rastvaranje razmaznog sloja na zidovima kanala i značajno doprinose njegovom uklanjanju $[22,23]$. Time se značajno povećava kvalitet veze sredstva za opturaciju za zidove kanala i značajno utiče na kvalitet i ishod samog endodontskog zahvata [24, 25].

Cilj ovog rada je bio da se SEM analizom proceni efikasnost čišćenja apeksne trećine kanala korena primenom novog rotirajućeg NiTi instrumenta XP-endo SHAPER (samo jedan instrument) uz protokol konvencionalne irigacije.

\section{MATERIJAL I METODE}

Istraživanje je obavljeno na 40 ekstrahovanih humanih zuba (gornjih sekutića) koji su do eksperimenata čuvani u 0,01\% rastvoru $\mathrm{NaOCl}$ na temperaturi $4^{\circ} \mathrm{C}$.

Kod svih zuba je posle formiranja pristupnog kaviteta $\mathrm{i}$ provere prohodnosti kanala instrumentom (ISO 15) određena radna dužina ( 1 mm kraće od dužine na kojoj se vrh ručne turpije pojavljuje na apeksu). Na vrhu korena svakog zuba je zatim postavljena kuglica roze voska kako bi se sprečilo isticanje rastvora za irigaciju tokom instrumentacije.

Metodom slučajnog izbora zubi su podeljeni u četiri grupe po 10 zuba. Kompletnu preparaciju kanala obavio je jedan istraživač. Za ispiranje su korišćeni plastični špricevi zapremine 2 $\mathrm{ml}$ i odgovarajuće igle veličine 27.

Grupa 1 - preparacija je realizovana primenom osnovnog seta NiTi rotirajućih instrumenata iRaCe (FKG, Dentaire, Swiss) [26] sa tri instrumenta $\left(\mathrm{R}_{1} \# 15 / 06 ; \mathrm{R}_{2} \# 25 / 04 ; \mathrm{R}_{3} \# 30 / 04\right)$ uz kontinuiranu konvencionalnu irigaciju $2 \%$ rastvorom $\mathrm{NaOCl}$ (Chloraxid 2\%, Cerkamed, Poland). Kanal je ispiran sa $2 \mathrm{ml}$ rastvora $\mathrm{NaOCl}$ pre svakog i posle poslednjeg NiTi instrumenta (ukupno $8 \mathrm{ml}$ po kanalu). 
Grupa 2 - instrumentacija kanala je urađena identično kao i u prvoj grupi, ali je posle završene instrumentacije kanala korišćen XP-endo FINISHER (FKG, Dentaire, Swiss). XPF je korišćen u kanalu ispunjenim irigansom $(1 \mathrm{ml} \mathrm{NaOCl})$ primenom sporih i nežnih pokreta uvlačenja i izvlačenja tokom jednog minuta i pri brzini od $800 \mathrm{o} / \mathrm{min}$. Posle izvlačenja instrumenta, kanal je ispran sa još $1 \mathrm{ml}$ rastvora.

Grupa 3 - instrumentacija kanala je obavljena novim NiTi rotirajućim instrumentom XP-endo SHAPER (XPF) (FKG, Dentaire, Swiss) [26] (jedan instrument \#30/04) uz konstantnu irigaciju $2 \%$ rastvorom $\mathrm{NaOCl}$ pre i posle instrumenta (ukupno 4 $\mathrm{ml}$ po kanalu). Instrument je ubačen u kanal ispunjen irigansom i nežnim pokretima uvlačenja i izvlačenja pri brzini od 800 o/min. kanal je preparisan do radne dužine.

Grupa 4 - instrumentacija kanala je realizovana identično kao i u trećoj grupi primenom XP-endo SHAPERA, a posle instrumentacije za efikasnije čišćenje je korišćen XP-endo FINISHER, identično kao i u drugoj grupi.

Krunice svih zuba su presečene u predelu gleđno-cementne granice, a potom korenovi dijamantskim diskom uzdužno zasečeni i uz pomoć oštrog nožića razdvojeni na dve polovine. Ovako dobijene polovine pripremljene su za SEM analizu (JOEL, JSM 6460LV, Japan). Analizirana je samo apeksna trećina kanala (region $3 \mathrm{~mm}$ od granice preparacije) tako što je za svaki uzorak (polovina zuba) napravljeno po pet standardizovanih mikrofotografija na uvećanju od 2000 puta. Za kvalitativnu procenu zaostalog razmaznog sloja na zidovima kanala u apeksnom segmentu korišćeni su kriterijumi Hilsmana i sar. [27]:

Ocena: 1 - nema razmaznog sloja, dentinski tubuli otvoreni; 2 - mala količina razmaznog sloja, nekoliko tubula otvoreno;

3 - nehomogeni razmazni sloj pokriva zid kanala, malo tubula otvoreno;

4 - ceo zid kanala pokriven razmaznim slojem, nema otvorenih tubula;

5 - nehomogeni razmazni sloj koji pokriva ceo zid kanala.

SEM fotografije uzoraka svih zuba (400 slika) procenjivala su dva nezavisna istraživača. Dobijeni rezultati su uređeni u SPSS programu i analizirani primenom parametara deskriptivne statistike i analize varijanse.

\section{REZULTATI}

Rezultati SEM analize apeksne trećine kanala korena zuba su prikazani u Tabeli 1 i slikama $1-4$.

Najviše razmaznog sloja u apeksnoj trećini zabeleženo je u grupi gde je instrumentacija realizovana samo NiTi rotirajućim instrumentima iRaCe [2,12] (Slika 1), potom u grupi gde je korišćen XP-endo SHAPER $(1,95)$ (Slika 2), dok je u drugoj (iRaCe i XP-endo FINISHER) (Slika 3) i četvrtoj grupi (XP-endo SHAPER i XP-endo FINISHER) (Slika 4) uočena identična i nešto manja količina razmaznog sloja $(1,64)$. Jednofaktorska analiza varijanse je ukazala na visoko statistički značajnu razliku u prosečnim ocenama između grupa $(\mathrm{p}<0,001)$ (Tabela 1$)$. Ova razlika je bila značajna između prve (iRaCe) i druge grupe (iRaCe i XPendo FINISHER), odnosno između prve (iRaCe) i četvrte grupe (XP-endo SHAPER i XP-endo FINISHER) (Tabela 1).

\section{DISKUSIJA}

Hemomehanička preparacija kanala korena zuba je jedan od presudnih faktora u kontroli endodontske infekcije [3, 7, 22], a uklanjanje razmaznog sloja sa zidova kanala korena značajan klinički parametar za uspeh endodontskog lečenja [13, 15, 25].

Poseban problem u čišćenju kanala korena i uklanjanju razmaznog sloja je područje granice instrumentacije, odnosno apeksna trećina kanala korena [6, 12, 18, 21]. Osnovni razlog za to je nepristupačnost ovog segmenta kanala, odnosno neadekvatan dijametar apeksne preparacije, ali i volumen, koncentracija i vreme izlaganja ovog dela kanala rastvoru za irigaciju $[7,10$, $13,28,29,30]$.

Zato je u ovom istraživanju instrumentacija i irigacija kanala realizovana na jednostavnim kanalnim sistemima (jednokoreni zubi), prema istom protokolu (sve kanale je obradio isti praktičar) uz isti irigans $(2 \% \mathrm{NaOCl}) \mathrm{i}$ istu tehniku irigacije (konvencionalna, kontinuirana), tako da se dobijeni rezultati mogu analizirati u funkciji korišćenih NiTi rotirajućih instrumenata i njihovoj efikasnosti u čišćenju apeksne trećine kanala.

Dobijeni rezultati su ukazali na značajno efikasnije čišćenje i uklanjanje razmaznog sloja u apeksnoj trećini kanala korena kada je poslen završene instrumentacije NiTi rotirajućim instrumentima (iRaCe, XP-endo SHAPER) korišćen XP-endo FINISHER. Primena ovog instrumenta obezbedila je efikasnije uklanjanje razmaznog sloja iz apikalnog segmenta kanala, jer zahavljujući specifičnom dizajnu i činjenici da menja svoj oblik tokom rotacije može da dopre i do nepristupačnih delova u apeksnom delu kanala $[6,18,20,26]$. Primena ovog instrumenta obezbeđuje značajno veću redukciju bakterija u kanalnom sistemu jer eliminiše bakterije iz teško dostupnih područja, zahvaljujući efektu aktivacije irigansa pri brzini od $800 \mathrm{o} / \mathrm{min}$. [6]. Potvrđeno je takođe da ključni deo čišćenja kanala korena zavisi od tehnike instrumentacije, odnosno izbora irigansa i tehnike irigacije $[2,8,10,12,16,18,24]$.

$\mathrm{U}$ ovom istraživanju je kao irigans korišćen $2 \%$ rastvor $\mathrm{NaOCl}$ i konvencionalni i kontinuirani protokol irigacije, dok je instrumentacija kanala u prvoj i drugoj grupi realizovana setom iRaCe NiTi rotirajućih instrumenata (tri instrumenta), a u trećoj i četvrtoj grupi sa XP-endo SHAPEROM (jedan instrument). Nešto bolje čišćenje apeksnog dela kanala i efikasnija hemomehanička preparacija je uočena posle primene XP-endo SHAPERA, ali bez značajnih razlika. Ova mala razlika bi se mogla objasniti istim dijametrom apeksne preparacije (\#30/04 kod iRaCe i \#30/04 kod XP-endo SHAPERA), a nešto bolji rezultat kod XP-endo SHAPERA specifičnim dizajnom ovog instrumenta i njegovom ekstremnom fleksibilnošću koja mu omogućava da se kontrahuje i širi unutar kanala i time dosegne i do onih zona do kojih konvencionalni instrumenti ne mogu [28].

Ono što je zanimljivo u rezultatima ovog istraživanja je činjenica da je efikasnije uklanjanje razmaznog sloja u apeksnoj trećini ostvareno kod kanala gde je preparacija urađena samo jednim instrumentom i sa znatno manjom količinom irigansa, odnosno sa kraćim vremenom delovanja na zidove kanala usled kraćeg vremena instrumentacije. Iako se veća bakterijska redukcija u kanalskom sistemu očekuje posle produžene irigacije $[13,31]$, nešto bolje čišćenje bi se ovde moglo objasniti upravo tehnikom instrumentacije odnosno nešto većom brzinom rotacije ( $800 \mathrm{o} / \mathrm{min}$.), ali i specifičnim dizajnom XP-endo SHAPERA. Naime, ,zmijoliki“ izgled i superelastičnost XP-endo 
SHAPERA omogućavaju mu da se „širi“ unutar kanala i tako dopre do nepristupačnih delova (istmusi, lateralni kanali, apeksne ramifikacije) kanala [20, 26, 28, 33, 34].

Efikasno čišćenje apeksnog dela kanala korena setom rotirajućih instrumenata $\mathrm{iRaCe}$ posledica je zadovoljavajućeg dijametra u apeksu (30/04), što obezbeđuje bolji efekat aplikovanog rastvora za irigaciju i njegov efikasniji rastvarački odnosno bolji efekat uklanjanja razmaznog sloja $[25,28,30]$. Potvrđeno je takođe da preparacija kanala RaCe instrumentima dovodi do znatno manje transportacije sečenog dentina u apeksni deo kanala $\mathrm{u}$ odnosu na druge rotirajuće NiTi instrumente [20,35]. Manja količina razmaznog sloja u apeksnom delu kanala posle preparacije iRaCe setom NiTi rotirajućih instrumenata može biti i posledica nešto veće brzine ovih instrumenata $(600 \mathrm{o} / \mathrm{min}$.) u odnosu na najčešće brzine drugih setova NiTi (150-300 o/min.) [20,36].

S obzirom na to da prisustvo bakterija u kanalskom sistemu uzrokuje lošu prognozu ishoda endodontskog lečenja, osnovni preduslov za uspeh je njihova maksimalna eliminacija hemomehaničkom instrumentacijom $[7,30]$. NaOCl je najčešće korišćen rastvor za irigaciju kanala korena zbog efikasnog antibakterij- skog i rastvaračkog efekta, odnosno brzine delovanja i njegove cene [30]. Na efikasnost uklanjanja razmaznog sloja sa zidova kanala korena može uticati i sam protokol odnosno tehnika irigacije [6]. Prednost intermitentnog postupka irigacije (u tri koraka) u odnosu na kontinuiranu je u tome što se povećanjem ciklusa irigacije povećava i njegov kumulativni efekat, jer se svežim irigansom poboljšavaju kvalitet i brzina čišćenja, ali i efikasno uklanjanje biofilma bakterija iz kanalskog sistema $[6,37,38]$.

\section{ZAKLJUČAK}

U okviru ograničenja ove studije može se zaključiti da se nakon instrumentacije kanala korena novim rotirajućim NiTi instrumentom - XP-endo SHAPER (jedan instrument) i seta iRaCe (tri instrumenta) obezbeđuje efikasno čišćenje apeksnog dela kanala korena. Primena XP-endo FINISHERA posle završene instrumentacije kanala instrumentom XP-endo SHAPER i setom iRaCe rotirajućih NiTi instrumenata dovodi do značajno efikasnijeg uklanjanja razmaznog sloja u apeksnom delu kanala korena. 